African Journal of Educational Studies in Mathematics and Sciences Vol. 16, No. 2, 2020

\title{
Biology Instructional Resources Availability and Extent of their Utilization in Teaching Pre-Service Biology Teachers
}

\author{
J. Mukagihana ${ }^{1}$, F. Nsanganwimana ${ }^{2}$, C. M. Aurah ${ }^{3}$
}

\section{Abstract}

Education of pre-service science teachers necessitates inquiry and resource-based instruction to ensure the production of both hands-on and mind-on skilled science teachers. This becomes possible when a variety of instructional resources regularly support the teaching process. This study aimed to identify the types of available biology instructional resources and their extent of use in teaching pre-service biology teachers. The study used a descriptive survey research design and was conducted in three private Universities selected from those offering education in Rwanda. Eightytwo pre-service biology teachers and five biology lecturers participated in the study. Observational checklist of biology instructional resources and questionnaires aided the collection of data analyzed by frequency counts and percentages. The findings revealed that biology instructional resources like classroom chairs, chalkboards, laboratories, microscopes, centrifuge, slide projectors, biology textbooks were available while resources like a class whiteboard, classroom overhead projectors, electrophoresis unit, recorders, Polymerase chain reaction machines, among others, were absent. The findings also revealed low-level use of available biology instructional resources in teaching pre-service biology teachers. The implication is the likelihood of producing less competent future biology teachers. The provision of adequate biology instructional resources, as well as the monitoring of their use in teaching biology, was recommended.

Keywords: availability, extent of utilization, biology instructional resources, pre-service biology teacher

\section{Introduction}

German colonials initiated the education system in Rwanda, and through the aid of missionaries, they initiated not only primary and secondary schools but also higher learning education. Missionaries were the provider of instructional resources, infrastructures, and other necessary educational materials to these schools. (Bizimana \& Orodho, 2014). The indication is that instructional resources supported teaching for years. Colleges of education and Universities with pre-service science teachers' programs must be well equipped with various instructional resources for

\footnotetext{
${ }^{1}$ Josiane Mukagihana, African Centre of Excellence for Innovative Teaching and Learning Mathematics and Science (ACEITLMS), University of Rwanda-College of Education (URCE), P.O Box 55 Rwamagana, Rwanda: ${ }^{1}$ Email: joaxmuka@yahoo.fr, Tel: +250781090474.

${ }^{2}$ Florien Nsanganwimana, African Centre of Excellence for Innovative Teaching and Learning Mathematics and Science (ACEITLMS), University of Rwanda-College of Education (URCE), P.O Box 55 Rwamagana, Rwanda, Email: florinsanga@yahoo.fr, Tel: +250783891757

${ }^{3}$ Catherine. M. Aurah, Masinde Muliro University of Science and Technology. Email: cataurah@yahoo.com, Tel: +25472496657 4.
}

Open Access article distributed under the terms of the Creative Commons Attributions License [CC BY-NC-ND 4.0] http://creativecommons.org/licenses/by-nc-nd/4.0. DOI: https://dx.doi.org/10.4314/ajesms.v16i.2.3 


\section{J. Mukagihana, F. Nsanganwimana, C. M. Aurah}

producing competent teachers (Nnorom \& Okoli, 2014). Instructional resources are materials that assist instructors in making the learning of concepts clear and understandable by students. They reduce oral teaching, increase learners' engagement, interest, and motivation toward learning sciences (Tuimur \& Chemwei, 2015).

Teaching biology as science requires not only theoretical but also practical skills that are transmitted to pre-service biology teachers through the use of instructional resources. With them, hands-on and critical thinking skills are developed in students. Their use in teaching pre-service science teachers build-up professional skills in them (Sonmez \& Hakverdi-Can, 2012), thus empowering kills to notice when and when not to use available materials in class when becoming professional teachers. Instructional resources innovatively support teachers to interchange the pedagogical model when teaching, and this ensures the production of professionally experienced teachers (Sasson et al., 2020). Beside, Instructional resources enable teachers to create methods of assessing students' performance (Arop et al., 2015). Therefore, their use in training pre-service biology teachers is a valuable fact as they create in them not only practical but also assessment skills. The use of Instructional resources in teaching allows teachers to specify class activities, thus ease the assessment of students' conceptual understanding as noted by Mukuka et al. (2020), who agreed that through class exercises, students' conceptual understanding is assessed. The types of instructional resources used in biology instructional methods are those instructive materials that aids instructors in effectively delivering biology lessons. They include print and non-print materials that aid instructors in involving students in the classroom activities.

The use of biology instructional resources has diverse importance not only for preservice biology teachers' education but also for all kinds of students, and their use becomes fruitful, especially when students manipulate the used materials. For instance, Adebule and Ayoola (2016) affirmed that instructional resources use in teaching raises students' level of discovery and stimulates students to learn more as they see what they are taught. Besides, (Johnson \& Cotterman 2015) found that the use of video clubs increased the pre-service science teachers' understanding of their science subject content. Technology related instructional resources are more imperative for training pre-service science teachers, as they afford the required technology skill essential for a qualified teacher of this digitalized world (Oren, 2017). Besides, Arokoyu and Chimuanya (2017) attested that the teaching process becomes less stressful for both teachers and students when instructional materials are used. Therefore, identifying available instructional materials at schools, especially at higher learning institutions, is of imperative need as learning by hands-on and observation of instructional resources raise students' level of memory and enhance learning achievement.

Olayinka (2016) confirmed that there is an excellent achievement for students taught with instructional resources comparing to those educated without any teaching material. The difference is because instructional materials ease the communication between teachers and students and promote active teaching and learning, thus facilitate understanding of concepts that become complex by words only. Ong' amo et al. (2017) attested that there are different instructional resources in the schools' environments for teaching 
African Journal of Educational Studies in Mathematics and Sciences Vol. 16, No. 2, 2020

biology. Moreover, those are present in diverse varieties that Science teachers can readily use. Effiong et al. (2015) found them to be materials that include chalkboards, diagrams, models, digitals tools, written texts, pictures, and recording videos, among others. Belachew (2020) classified texts in two versions that can be used in science education like traditional texts that are universally used as textbooks, standard references, and conceptual change texts. Okpechi and Denwigwe (2017), in their study, listed several biology instructional resources that, among others, include different types of projectors like "film loop projector, slide projector, micro projector, overhead projector, and opaque projector" (p.14).

Bosibori et al. ( 2015), Musah and Umar (2017) classified instructional resources used in biology instructional methods in different categories like material resources, human resources, and physical resources. Arop et al. (2015) categorized types of resources used in biology instructional methods into three main types: Visual, audio, and audiovisual resources. Visual resources support instruction through sight, and students can manipulate them; they include flashcards, posters, charts, textbooks, real objects, models, chalkboards, images, among others. Audio resources support instruction through hearing; they include tape recorders and radios, among others. Audiovisual resources are those instructional resources that teachers use as a combination of audio and visual tools; they stimulate sight and hearing sense. Computers, television, tape recorder, radios, videos are excellent examples. Iji et al. (2014) attested that they could be made from industries, or by teachers, or students made from locally available materials through the concept of materials improvisation. Therefore, the particularity is that the present study categorized biology instructional resources as classroom resources, basic biology laboratory resources, library resources, and ICT resources. The justification of this classification is that they wrap the importantly needed instructional resources for biology teaching and learning in higher learning institutions.

In 2015, Rwanda had reformed the education curriculum and shifted from knowledge-based to a competence-based curriculum (CBC). The change was needed to develop new skills in Rwandan students that, among others, include problem-solving skills, critical thinking skills, life skills, creativity, innovation, and application skills (Ngendahayo \& Williams, 2016). Ndihokubwayo et al. (2019) defined a competence-based curriculum as a curriculum that emphasizes what students must hands-on rather than accentuating what they have to know. Besides, students in $\mathrm{CBC}$ are expected to actively participate in all teaching activities (Ndihokubwayo et al., 2020). However, this is successfully achieved when instructional resources support teaching environments. Such type of curriculum, in the presence of a variety of instructional resources, allows instructors to create active teaching and learning environment that provide full occasions and adequate time for students' collaborations by winning them to independently develop skills and real understanding (Byusa et al., 2020). To be well implemented, CBC requires a well-skilled and trained science teacher with both minds and hands-on skills. Therefore pre-service biology teachers must well be trained using a variety of instructional resources.

From the literature search, researchers identified types of instructional resources that are ready to teach biology at elementary schools. However, little literature highlighted the types of biology 


\section{J. Mukagihana, F. Nsanganwimana, C. M. Aurah}

instructional resources for training preservice biology teachers at teacher training higher learning institutions. Therefore, the hard work for this exploration was of an imperative need to add to the literature the status of types of biology instructional resources available in higher institutions that train pre-service biology teachers. The reason why this study focused on that and the benefits are for all teacher training higher learning institutions and colleges worldwide. Different factors contribute to pre-service science teachers' pedagogical knowledge development. Among others, instructional resources are of treasured importance when appropriately are used in teaching activities as they promote the skills of linking the knowledge of subject content to the knowledge of the pedagogical model required (Sonmez \& Hakverdi-Can, 2012). This makes a call to the exploration of the extent to which instructional materials are used in teaching pre-service science teachers. However, this study significantly contributed by providing an insight to that urgent call.

Biology is the science of life and, its concepts support human beings for understanding themselves and their environments. This makes it a subjet of must that should be taught with instructional resources at all levels of education. Studies in the area of biology instructional resources and their effect on students' learning outcomes are many, but considerable interest was mostly at primary and secondary schools. As well in Rwanda, the studies were not silent in this area of research, but the tertiary level was a little bit emphasized. Besides, only slight studies focused on biology instructional resources in private institutions that train pre-service biology teachers. Pre-service teachers, as the teachers in the future, are anticipated to implement a competency-based curriculum
(CBC) that requires them to have enough practical skills. It is with those inspirations that, to fill the gap, the study aimed at finding the answers to the following two research questions:

1) What are the types of available biology instructional resources for teaching preservice biology teachers in Private Universities in Rwanda?

2) To what extent the available types of biology instructional resources are used in teaching pre-service biology teachers in Private Universities in Rwanda?

\section{Methodology}

\section{Research Design and Sampling Techniques}

The present study aimed to identify the types of available biology instructional resources and determine the extent to which preservice biology teachers are taught using biology instructional resources in private Universities in Rwanda.

The study employed a descriptive survey design (Fraenkel et al., 2012). The research design was selected because it would help to explore the types of available instructional resources and to describe their extent use in teaching pre-service biology teachers in Private Universities in Rwanda. The target population consisted of all (28) accredited Private Universities in Rwanda. Stratified sampling technique was used to put private Universities into strata based on the presence or the absence of biology education programs and the presence of students (preservice biology teachers) in level $3 \& 4$ (year three). Those without biology education programs and those with but without preservice biology teachers in level $3 \& 4$ were filtered out; thus, respondents from three (3) Private Universities participated in the study. Purposive sampling was used to select pre-service biology teachers as respondents 
African Journal of Educational Studies in Mathematics and Sciences Vol. 16, No. 2, 2020

based on criteria of being in level $3 \& 4$ (year three) biology Education. The condition was of choice because they are majoring in biology education and being biology teachers in the future. Besides, they are more likely to be aware of how biology is taught at their universities. The total population of pre-service biology teachers in level $3 \& 4$ biology education being small (82) means less than 200; they were all sampled by the Census approach of sample size determination (Naing, 2003). A convenient sampling helped to select five (5) biology lecturers in faculties of education based on their availability at their Private Universities on the day of data collection (for sample size, see Table 1).

\begin{tabular}{lcc} 
Table 1 & \multicolumn{2}{c}{$\begin{array}{l}\text { Distributions of respondents } \\
\text { in sample }\end{array}$} \\
\hline $\begin{array}{l}\text { Private } \\
\text { universities }\end{array}$ & $\begin{array}{l}\text { Pre-service } \\
\text { biology } \\
\text { teachers }\end{array}$ & $\begin{array}{l}\text { Biology } \\
\text { lecturers }\end{array}$ \\
\hline code & 12 & 1 \\
A & 33 & 2 \\
B & 37 & 2 \\
C & $\mathbf{8 2}$ & $\mathbf{5}$ \\
Total &
\end{tabular}

With data collection permits, we got an ethical clearance from the research and innovation unit at the University of Rwanda College of Education and research permits from the three Private Universities

\section{Data Collection Instruments}

We collected data using two instruments. The first instrument was an observational checklist developed to identify the types of available biology instructional resources at three selected private Universities. The biology instructional resources were categorized into Classroom instructional resources, Basic Biology laboratory instructional resources, Library instructional resources, and ICT instructional resources.
In each category, different items referred to during observation were specified. Their adequacy counts, and existing conditions were not focused. The second instruments were two questionnaires - one for Preservice biology teachers and the other for Biology lecturers developed to supplement the information from the observation checklist and to measure the extent of use of available types of biology instructional resources in teaching pre-service biology teachers. We had the validity of our instruments checked by experts in biology Education at the University B. Pre-servicebiology teachers' questionnaire was reliable as by omitting four (4) statements out of twenty (20), the internal consistency using KR21 was found to be 0.7 , which considered acceptable (Fraenkel et al., 2012).

Through the guidance of human resources in charge of units at three selected Private Universities, the first researcher observed and ticked in the appropriate place relating items to available or not available. Preservice biology teacher's questionnaires (PBTQ) were administered to level $3 \& 4$ (year three) pre-service biology teachers to collect information about the types of available resources and the extent of how they are taught using Instructional resources. The questionnaire was a closed-ended type (Yes or No) in the form of a table with 16 statements. Biology lecturers' questionnaire (BLQ) was settled to gather information from lecturers about the types of available biology instructional resources and the extent they utilize them in teaching preservice biology teachers. To provide answers, biology lecturers ticked in the appropriate place relating a resource to either "Present and mostly used, Present and rarely used, Present and not used, finally absent and never used. 
Biology Instructional Resources Availability and Extent of their Utilization in Teaching PreService Biology Teachers

\section{J. Mukagihana, F. Nsanganwimana, C. M. Aurah}

\section{Data analysis}

Based on research questions, we analyzed our collected data descriptively where frequency counts of universities considering availability and non-availability of materials, frequency counts of respondents based on their agreements, and percentages were used. Researchers maintained the confidentiality, privacy, and security of the collected data so that no participants' identity has been mentioned in the findings' presentation and discussion.

\section{Results presentation}

\section{Types of Available Biology Instructional Resources}

To answer the first research question about the types of available instructional resources in teaching pre-service biology teachers in Private Universities in Rwanda, we presented the findings in Tables 2 to 5 . classroom overhead projectors, University Frequency Counts, and the percentage of availability was $0(0 \%)$ while not available are $3(100 \%)$. At $2(67 \%)$ Private Universities, lecturers' tables were observed in every classroom while absent at the other $1(33 \%)$.

Biology laboratory was observed at all $3(100 \%)$ private Universities, as indicated in Table 3, Most of the basic biology laboratory resources were present. Few resources like electophoresis unit, PCR (Polymerase chain reaction) machine, Chromatography equipment, Spectrophotometer, Voltmeter, Benedict's Reagent, DNS (3,5dinitrosalicylic acid) solution, Starch test reagent (Iodine solution), and Vitamin $\mathrm{C}$ test reagent (Dichlorophenol indophenol) were absent at all three private Universities. Resources like Water bath, Specimen Bottles, Evaporating Dishes, Turbidity

Table 2: $\quad$ Responses on classroom instructional resources available for teaching pre-service biology teachers in private universities

\begin{tabular}{clcc}
\hline & & \multicolumn{2}{c}{ Number indicating } \\
\cline { 3 - 4 } S/N & Items & Available & Not available \\
\hline 1 & Class rooms & $3(100)$ & $0(0)$ \\
2 & Students' chairs & $3(100)$ & $0(0)$ \\
3 & Classroom white board & $1(33)$ & $2(67)$ \\
4 & Classroom chalk board & $3(100)$ & $0(0)$ \\
5 & Classrooms electrical outlets & $3(100)$ & $0(0)$ \\
6 & Classroom overhead projectors & $0(0)$ & $3(100)$ \\
7 & Lecturer' Tables & $2(67)$ & $1(33)$ \\
\hline
\end{tabular}

Percentages in parenthesis

In Table 2, the finding shows that classrooms students' chairs, classroom chalkboards, and electrical outlets were found to be present at all 3(100\%) selected Private Universities. Class whiteboards were found to be presents only at $1(33 \%)$ Private University among three and absents to $2(67 \%)$ others. All three private universities lacked classroom fixed projectors known as meter, Models (various types), protein's test reagent (Biuret reagent) were found at $1(33 \%)$ University. Biology laboratory resources such as Gram-stain reagents, Culture media preparations reagents, Plates, Laminar Flow Chamber, Charts, Fehling's solution were observed at 2(67\%) Private Universities and absent at another 1(33\%). 
African Journal of Educational Studies in Mathematics and Sciences Vol. 16, No. 2, 2020

Table 3 Responses on basic biology instructional resources available for teaching preservice biology teachers in private universities

\begin{tabular}{|c|c|c|c|}
\hline \multirow[b]{2}{*}{$\mathrm{S} / \mathrm{N}$} & \multirow[b]{2}{*}{ Items } & \multicolumn{2}{|c|}{ Number indicating } \\
\hline & & Available & Not Available \\
\hline 1 & Presence of Biology laboratory & $3(100)$ & $0(0)$ \\
\hline$\underline{2}$ & Microscope and its related equipment & $3(100)$ & $0(0)$ \\
\hline$\overline{3}$ & Gram-stain reagents & $2(67)$ & $1(33)$ \\
\hline 4 & Autoclave & $3(100)$ & $0(0)$ \\
\hline 5 & Culture media preparations reagents & $2(67)$ & $1(33)$ \\
\hline 6 & Refrigerator & $3(100)$ & $0(0)$ \\
\hline 7 & Incubators & $3(100)$ & $0(0)$ \\
\hline 8 & Water bath & $1(33)$ & $2(67)$ \\
\hline 9 & Chemical balance & $3(100)$ & $0(0)$ \\
\hline 10 & $\mathrm{pH}$ meter & $3(100)$ & $0(0)$ \\
\hline 11 & Standards pipette & $3(100)$ & $0(0)$ \\
\hline 12 & Graduate cylinder & $3(100)$ & $0(0)$ \\
\hline 13 & Beakers & $3(100)$ & $0(0)$ \\
\hline \multirow[t]{2}{*}{14} & Erlenmeyer flask (a) flat bottom & $3(100)$ & $0(0)$ \\
\hline & Erlenmeyer flask (b) Round bottom & $3(100)$ & $0(0)$ \\
\hline 15 & Bell Jars & $3(100)$ & $0(0)$ \\
\hline 16 & Specimen Bottles & $1(33)$ & $2(67)$ \\
\hline 17 & Electrophoresis unit & $0(0)$ & $3(100)$ \\
\hline 18 & PCR instrument & $0(0)$ & $3(100)$ \\
\hline 19 & Microwave & $3(100)$ & $0(0)$ \\
\hline 20 & Centrifuge & $3(100)$ & $0(0)$ \\
\hline 21 & Bunsen burner & $3(100)$ & $0(0)$ \\
\hline 22 & Magnetic stirre & $3(100)$ & $0(0)$ \\
\hline 23 & Chromatography equipment & $0(0)$ & $3(100)$ \\
\hline 24 & Plates & $2(67)$ & $1(33)$ \\
\hline 25 & Evaporating dishes & $1(33)$ & $2(67)$ \\
\hline 26 & Spectrophotometer & $0(0)$ & $3(100)$ \\
\hline 27 & Voltmeter & $0(0)$ & $3(100)$ \\
\hline 28 & Test tube & $3(100)$ & $0(0)$ \\
\hline 29 & Flask & $3(100)$ & $0(0)$ \\
\hline 30 & Reagent funnel & $3(100)$ & $0(0)$ \\
\hline 31 & Latex Gloves & $3(100)$ & $0(0)$ \\
\hline 32 & Hot Air Oven for Sterilization & $3(100)$ & $0(0)$ \\
\hline 33 & Drying Oven & $3(100)$ & $0(0)$ \\
\hline 34 & Laminar Flow Chamber & $2(67)$ & $1(33)$ \\
\hline 35 & Turbidity meter & $1(33)$ & $2(67)$ \\
\hline 36 & Molter and pestle & $3(100)$ & $0(0)$ \\
\hline 37 & Models ( various types) & $1(33)$ & $2(67)$ \\
\hline 38 & Charts & $2(67)$ & $1(33)$ \\
\hline 39 & Spatula & $3(100)$ & $1(0)$ \\
\hline 40 & Proteins test reagent: Biuret reagent & $1(33)$ & $2(67)$ \\
\hline \multirow[t]{3}{*}{41} & Sugar test reagents: a) Benedict's Reagent & $0(0)$ & $3(100)$ \\
\hline & b) Fehling's solution & $2(67)$ & $1(33)$ \\
\hline & c) DNS $(3,5)$-dinitrosalicylic acid solution & $0(0)$ & $3(100)$ \\
\hline 42 & Starch test reagent: Iodine solution & $0(0)$ & $3(100)$ \\
\hline 43 & Fat test reagent: Ethanol & $3(100)$ & $0(0)$ \\
\hline 44 & Vitamin C test reagent: Dichlorophenol indophenol & $0(0)$ & $3(100)$ \\
\hline
\end{tabular}

Percentages in parenthesis 
Biology Instructional Resources Availability and Extent of their Utilization in Teaching PreService Biology Teachers

J. Mukagihana, F. Nsanganwimana, C. M. Aurah

Table 4 Responses on library instructional resources available for teaching pre-service biology teachers in private universities

\begin{tabular}{llcc}
\hline & & \multicolumn{2}{c}{ Number of respondents indicating } \\
\cline { 3 - 4 } S/N & Items & Available & Not Available \\
\hline 1 & Presence of library & $3(100)$ & $0(0)$ \\
2 & Reading place for students in library & $3(100)$ & $0(0)$ \\
3 & Biology textbooks & $3(100)$ & $0(0)$ \\
4 & Biology project dissertations/ memoirs & $1(33)$ & $2(67)$ \\
5 & Computers workstations & $3(100)$ & $0(0)$ \\
6 & Biology lessons' video recordings & $0(0)$ & $3(100)$ \\
7 & E-Journals & $0(0)$ & $3(100)$ \\
8 & Library internet facilities & $3(100)$ & $0(0)$ \\
9 & Electronic textbooks & $3(100)$ & $0(0)$ \\
10 & Biology lessons 'audio recordings & $0(0)$ & $3(100)$ \\
\hline \multicolumn{2}{c}{ Percentages in parenthesis }
\end{tabular}

Table 4 illustrates the types of library resources for teaching pre-service biology teachers and their availability at three selected private universities. It revealed that library resources like biology lessons' video recordings $0(0 \%)$, Biology lessons' audio recordings $0(0 \%)$, and e-journals $0(0 \%)$ were absent to all three selected Private Universities. $1(33 \%)$ Private University indicated the storage of biology project dissertations/ memoirs, while 2(67\%) showed that they are not available. All $3(100 \%)$ selected private universities indicated that library reading places for students, biology textbooks, computer workstations, electronic textbooks, and Library internet facilities are available.
As shown in Table 5, three selected Private Universities lacked the most necessary ICT resources for teaching biology. For instance, ICT resources like audio facilities for biology instruction $0(0 \%)$, audio-visual facilities $0(0 \%)$, videotape for biological process $0(0 \%)$, the digital camera $0(0 \%)$, scanners for students' services $0(0 \%)$, smart boards $0(0 \%)$, free wireless Network and University laptop for use in teaching biology were all absent. All 3(100\%) Private Universities indicated the presence of ICT resources like projectors, students' computer facilities, internet connectivity, printers, and photocopiers 
African Journal of Educational Studies in Mathematics and Sciences Vol. 16, No. 2, 2020

Table 5 Responses on ICT resources available for teaching pre-service biology teachers in private universities

\begin{tabular}{llcc}
\hline & & \multicolumn{2}{c}{ Number of respondents indicating } \\
\cline { 2 - 4 } S/N & Items & Available & Not available \\
\hline 1 & Portable projectors & $3(100)$ & $0(0)$ \\
2 & Students computer facilities & $3(100)$ & $0(0)$ \\
3 & Audio facilities for biology teaching & $0(0)$ & $3(100)$ \\
4 & Audio - visual facilities for biology teaching & $0(0)$ & $3(100)$ \\
5 & Internet connectivity & $3(100)$ & $0(0)$ \\
6 & Free wireless Network & $0(0)$ & $3(100)$ \\
7 & Videotape for biological process & $0(0)$ & $3(100)$ \\
8 & Digital camera & $0(0)$ & $3(100)$ \\
9 & University laptop for use in teaching biology & $0(0)$ & $3(100)$ \\
10 & recorders & $0(0)$ & $3(100)$ \\
11 & Computer simulation software & $0(0)$ & $3(100)$ \\
12 & Printers & $3(100)$ & $0(0)$ \\
13 & Photocopiers & $3(100)$ & $0(0)$ \\
14 & Scanners for students' services & $0(0)$ & $3(100)$ \\
15 & Smart boards & $0(0)$ & $3(100)$ \\
\hline \multicolumn{2}{c}{ Percentages in parenthesis } & &
\end{tabular}

\section{The Extent of Usage of Available Biology Instructional Resources}

To answer our second research question about the extent of the usage of available types of biology instructional resources in teaching pre-service biology teachers in three selected Private Universities in Rwanda, we presented our data in Tables 6 and 7.

The findings in Table 6 reveal that though $74(90.2 \%)$ out of eighty-two (82) preservice biology teachers said that their universities have adequate biology instructional resources, only $6(7.3 \%)$ preservice biology teachers posited that always biology lecturers use instructional resources during biology lessons. Following the negative response from $48(58.5 \%)$ out of eighty-two (82) respondents, pre-service biology teachers are not taken on a field trip to study using environmental resources. Considering the views from $67(81.7 \%)$ preservice biology teachers out 82 who participated in the study, three private universities have a well-equipped biology laboratory with most of the basic biology laboratory resources. This supplement the findings from the observational checklist. 
Biology Instructional Resources Availability and Extent of their Utilization in Teaching PreService Biology Teachers

J. Mukagihana, F. Nsanganwimana, C. M. Aurah

Table 6 Distribution of pre-service biology teachers agreeing to statements about availability of biology instructional resources and their use in lessons/lectures

\begin{tabular}{|c|c|c|c|}
\hline \multirow[b]{2}{*}{$\mathrm{S} / \mathrm{N}$} & \multirow[b]{2}{*}{ Statements } & \multicolumn{2}{|c|}{ Number of respondents } \\
\hline & & Agreeing & Disagreeing \\
\hline 1 & $\begin{array}{l}\text { Our University has adequate biology instructional } \\
\text { resources. }\end{array}$ & $74(90.2)$ & $8(9.8)$ \\
\hline 2 & $\begin{array}{l}\text { Always biology lecturers use instructional resources } \\
\text { during a biology lesson. }\end{array}$ & $6(7.3)$ & $76(92.7)$ \\
\hline 3 & $\begin{array}{l}\text { Lecturers take us on a field trip to study using } \\
\text { environmental resources. }\end{array}$ & $34(41.5)$ & $48(58.5)$ \\
\hline 4 & $\begin{array}{l}\text { At our University, biology is taught by qualified } \\
\text { biology lecturers. }\end{array}$ & $68(82.9)$ & $14(17.1)$ \\
\hline 5 & $\begin{array}{l}\text { University has a well-equipped biology laboratory with } \\
\text { basic biology laboratory resources. }\end{array}$ & $67(81.7)$ & $15(18.3)$ \\
\hline 6 & All biology concepts are taught in the laboratory. & $35(42.7)$ & $47(57.3)$ \\
\hline 7 & $\begin{array}{l}\text { University has a well-equipped laboratory, and biology } \\
\text { concepts requiring laboratory facilities are regularly } \\
\text { taught in the laboratory. }\end{array}$ & $40(48.8)$ & $42(51.2)$ \\
\hline 8 & We utilize the biology laboratory adequately. & $28(34.1)$ & $54(65.9)$ \\
\hline 9 & $\begin{array}{l}\text { University has ICT instructional resources for Biology } \\
\text { teaching. }\end{array}$ & $11(13.4)$ & $71(86.6)$ \\
\hline 10 & $\begin{array}{l}\text { At our University, audiovisual instructional materials } \\
\text { are used in teaching Biology. }\end{array}$ & $24(29.3)$ & $58(70.7)$ \\
\hline 11 & $\begin{array}{l}\text { Lecturers use portable projectors and laptops as ICT } \\
\text { instructional resources in teaching biology concepts. }\end{array}$ & $42(51.2)$ & $40(48.8)$ \\
\hline 12 & $\begin{array}{l}\text { University has a library with sufficient biology } \\
\text { textbooks. }\end{array}$ & $71(86.6)$ & $11(13.4)$ \\
\hline 13 & $\begin{array}{l}\text { Most of the time, lecturers teach biology using hand- } \\
\text { outs and biology textbooks as instructional resources. }\end{array}$ & $24(29.3)$ & $58(70.7)$ \\
\hline 14 & $\begin{array}{l}\text { Even though biology instructional resources are } \\
\text { available at our University, we are taught biology } \\
\text { concepts only by lecturing methods. }\end{array}$ & $29(35.4)$ & $53(64.6)$ \\
\hline 15 & $\begin{array}{l}\text { A large number of students in class is the most factor } \\
\text { preventing Biology lecturers from using Instructional } \\
\text { resources in teaching. }\end{array}$ & $29(35.4)$ & $53(64.6)$ \\
\hline 16 & $\begin{array}{l}\text { All biology modules learned were taught using biology } \\
\text { instructional resources. }\end{array}$ & $19(23.2)$ & $63(76.8)$ \\
\hline
\end{tabular}

Percentages in parenthesis 
African Journal of Educational Studies in Mathematics and Sciences Vol. 16, No. 2, 2020

Regarding the extent use of laboratory instructional materials, the majority of preservice biology teachers, 47(57.3\%), said that all biology concepts are not taught in the laboratory. In the same view of 54(65.9\%) and $42(51.2 \%)$ pre-service biology teachers out of eighty-two (82), respectively, biology laboratory resources are not used adequately as all biology concepts requiring laboratory facilities are not regularly taught in the laboratory. This implies low-level use of biology laboratory resources, which vigorously promotes students' hands-on and critical thinking skills. $71(86.6 \%)$ preservice biology teachers said that Universities do not have enough ICT instructional resources for teaching biology. That supplement the findings of observation, where most ICT instructional resources were absent. The findings also revealed the lowlevel use of ICT instructional resources as indicated by $58(70.7 \%)$ that at their Universities, audiovisual instructional resources are not used in teaching biology. The most used ICT instructional resources are portable projectors, as posited by $42(51.2 \%)$ pre-service biology teachers out of 82 who participated in the study. All biology modules learned were not taught using biology instructional resources as confirmed by the majority $63(76.8 \%)$, while only $19(23.2 \%)$ pre-service biology teachers said yes.

As indicated in Table 7, among the 26 biology instructional resources, only 11 were confirmed to be used while 15 others were not. The findings revealed that instructional resources such audiovisual materials, botanical gardens, university laptops, class whiteboards, Benedict's Reagent, DNS (3,5)-dinitrosalicylic acid solution, Starch test reagent (iodine solution), Vitamin $\mathrm{C}$ test reagent (Dichlorophenol indophenol), Simulations software, PCR machine, Electrophoresis units were all absent and never used. Few are present and mostly use while others are present but rarely used, present but not used. This implies that available biology instructional resources are used at a low level for teaching pre-service biology teachers in three selected private Universities in Rwanda. 
Biology Instructional Resources Availability and Extent of their Utilization in Teaching PreService Biology Teachers

J. Mukagihana, F. Nsanganwimana, C. M. Aurah

Table 7 Biology Lecturers' views on the availability, and extent of their use, of instructional resources in teaching pre-service biology teachers

\begin{tabular}{|c|c|c|c|c|c|c|}
\hline $\mathrm{S} / \mathrm{N}$ & Resource items & $\begin{array}{l}\text { Present } \\
\text { and } \\
\text { mostly } \\
\text { used }\end{array}$ & $\begin{array}{l}\text { Present } \\
\text { and } \\
\text { Rarely } \\
\text { used }\end{array}$ & $\begin{array}{l}\text { Present } \\
\text { and } \\
\text { not } \\
\text { used }\end{array}$ & $\begin{array}{l}\text { Absent } \\
\text { and } \\
\text { never } \\
\text { used }\end{array}$ & $\begin{array}{l}\text { Interpre- } \\
\text { Tation }\end{array}$ \\
\hline 1 & Projectors & $5(100)$ & & & & Used \\
\hline 2 & Biology laboratory & $1(20)$ & $1(20)$ & $3(60)$ & & Not Used \\
\hline 3 & Microscope & $2(40)$ & & $2(40)$ & $1(20)$ & Not Used \\
\hline 4 & Audio-Visual Materials & & & & $5(100)$ & Not Used \\
\hline 5 & Botanical gardens & & & & $5(100)$ & Not Used \\
\hline 6 & Library Resources & $5(100)$ & & & & Used \\
\hline 7 & Biology text Books & $5(100)$ & & & & Used \\
\hline 8 & Biology hand outs & $5(100)$ & & & & Used \\
\hline 9 & Computer- laboratory & $2(40)$ & & $2(40)$ & $1(20)$ & Not Used \\
\hline 10 & University lap-tops & $1(20)$ & & & $4(80)$ & Not Used \\
\hline 11 & Class white board & & $1(20)$ & & $4(80)$ & Not Used \\
\hline 12 & Class chalk board & $5(100)$ & & $(0)$ & & Used \\
\hline 13 & Lecturer's Lap-top & $5(100)$ & & () & & Used \\
\hline 14 & University internet access & $4(80)$ & & $1(20)$ & & Used \\
\hline 15 & Personal smart phone & $5(100)$ & & & & Used \\
\hline 16 & Gram-stain reagents & $3(60)$ & $1(20)$ & $1(20)$ & & Used \\
\hline \multirow[t]{4}{*}{17} & Sugar test reagents: & & & & & \\
\hline & a) Benedict's Reagent & & & $1(20)$ & $4(80)$ & Not Used \\
\hline & b) Fehling's solution & $2(40)$ & $1(20)$ & $2(40)$ & & Used \\
\hline & $\begin{array}{l}\text { c) DNS }(3,5) \text {-dinitrosalicylic acid } \\
\text { solution }\end{array}$ & & & & $5(100)$ & Not Used \\
\hline 18 & Starch test reagent: Iodine solution & & & $1(20)$ & $4(80)$ & Not Used \\
\hline 19 & Fat test reagent: Ethanol & $5(100)$ & & & & Used \\
\hline 20 & $\begin{array}{l}\text { Vitamin C test } \\
\text { reagent:(Dichlorophenol } \\
\text { indophenol) }\end{array}$ & & & $1(20)$ & $4(80)$ & Not Used \\
\hline 21 & Simulations software & & & & $5(100)$ & Not Used \\
\hline 22 & PCR machine & & & & $5(100)$ & Not Used \\
\hline 23 & Electrophoresis System & & & & $5(100)$ & Not Used \\
\hline 24 & Chemical balance & $2(40)$ & & $3(60)$ & & Not Used \\
\hline 25 & $\mathrm{pH}$ meter & $4(80)$ & $1(20)$ & & & Used \\
\hline 26 & Standards pipette & $2(40)$ & & $3(60)$ & & Not Used \\
\hline
\end{tabular}


African Journal of Educational Studies in Mathematics and Sciences Vol. 16, No. 2, 2020

\section{Discussion}

Our first research question sought to find out the types of available biology instructional resources for teaching pre-service biology teachers in Private Universities in Rwanda. In response, the findings revealed that three selected private Universities are equipped with classroom instructional resources; the absent to all were classroom overhead projectors and class whiteboard to two private universities. The findings diverge to what Bizimana and Orodho (2014) and Byusa et al. (2020b) noticed in their study, where insufficiency of classroom resources availability was observed due to different factors, including inadequate schools financial support. The fact that overhead projectors were absent to all three selected private universities may be due to the management and sharing culture for cost reduction. Thus, instead of purchasing projectors to be fixed in classrooms, they get more portable projectors that could be shared by lectures from one class to another. This implies the stress caused to biology lectures for the use of that illustrative instructional resource, and it may influence the teaching in the abstract. Besides, Oren (2017) proved that among the technologies preferred by pre-service science teachers to use in their teaching skills presentation include overhead projectors for the purpose that instructional material eases the communication with students and facilitated them to translate the abstract to the real concept. This implies that overhead projectors use in teaching pre-service biology teachers may equip them with the teaching skills they may use in microteaching or teacher practice. Thus, the overhead projectors' absence tells that preservice biology teachers may learn in the abstract and that they may not get easily use the same material when working as professional teachers.
Although all three private Universities possess biology laboratories with the most basic laboratory resources, however, the results also indicated the lack of some essential resources that are in line with modern biology education. Among others, those are like electrophoresis unit, PCR instrument, and spectrophotometer, voltmeter, and gram-stain reagents. The later, especially electrophoresis and PCR, are more significant in molecular biology, which currently makes part of the secondary school biology curriculum to analyze biological macromolecules like DNA, RNA, and proteins (Cunningham et al., 2006). The use of electrophoresis engage the students in experimental studies and increase their manipulation skills (Tan et al., 2007). Therefore, the absence of these instruments in training pre-service biology teachers may mark their incompetence to teach biological experiments like those related to gene technology as they require skills on the use of PCR machine and electrophoresis equipment. The finding also agrees with Obomanu (2011), who noted that the absence of laboratory resources justifies the lack of students' practical activities, and this explains the lack of knowledge of practice, which is built through practice, as noted by Min et al. (2017). The lack of knowledge of practice may result in low experimentally skilled biology teachers who are unable to implement $\mathrm{CBC}$ that require inquiry and resources base learning. Thus, it may lower the quality of education that pre-service teachers are anticipated to improve.

The findings revealed the unavailability of biology lessons' video recordings and biology lessons' audio recordings in the library. These lesson recordings support preservice biology teachers' self-study by accessing teachers/lecturers' elucidations after class, thus increase their knowledge integration. This unavailability may indicate 


\section{J. Mukagihana, F. Nsanganwimana, C. M. Aurah}

the limitation of digital library instructional resources to pre-service biology teachers and the significance that pre-service biology teachers who missed class or left behind in understanding have no chance to access lessons after the lecture. That might be the factor that can lower pre-service biology teachers' ability to visit the library and influence the culture of relying on lectures' hand-outs or their skills. The findings agree with Basheer and Ambreen(2012), who noted that students, when confronting a limited learning environment, could decide to apply the skills which they already have.

The findings also indicated the status of ICT instructional resources' availability in three selected private Universities in Rwanda. It revealed that most ICT instructional resources are not available. Only a few, including portable projectors, were available. The high cost of ICT materials may cause this absence of many ICT instructional resources. The same challenge also was recognized by Akuma \& Callaghan (2016), who noted that in many developing countries, it is difficult to find science handson instructional materials due to their expensiveness. That implies the limitation of using ICT resources in training pre-service biology teachers. Therefore they may become more dependent on lecturers' handouts, textbooks, and slide notes projected in class with available projectors. Pre-service biology teachers with sight disabilities if presents become restricted in learning due to absenteeism of ICTs supporting materials like recorders and audio facilities. Audiovisual materials have no trace of availability and later not only increase students' motivation and interest in learning biology but also minimize verbal teaching, thus increase students' concept retention (Akram \& Malik, 2012). Training pre-service biology teachers without audio-visual materials may influence subject memorization and reduce their knowledge transfer and application capability. The findings line with Bitok (2014), who noticed the unavailability of necessary biology ICT instructional resources in secondary schools where he detected that only calculators were the most available $(80 \%)$ for teaching/learning of Biology.

Our second question aimed to ascertain the extent use of available types of biology instructional resources for teaching preservice biology teachers in Private Universities in Rwanda. In response, the findings revealed a low-level use of available types of biology instructional resources. For instance, Pre-service biology teachers 54(65.9\%) posited inadequate use of biology laboratory resources, and 48 $(58.5 \%)$ claimed that they are not taken in the field to study using environmental resources. This low-level use of available instructional resources may be linked to various factors that, among others, may include the insufficiency of available biology instructional resources. The implication is that some biology concepts may be delivered in abstract, and teaching in abstract may decrease students' incentive for learning. This was ascertained by Niyukuri et al. (2020), who noticed that students could like to study when taught using materials. The low-level use of available instructional resources may also be coupled to uncomfortable lecturers to use instructional resources in class as posited by Pietzner (2014) that teachers being positive toward the usage of computers in teaching. However, they still present responses that indicate they are uncomfortable to use it in class. Beside, Romero-Tena et al. (2020), in their studies, noticed a low-level use of technology-related instructional resources in class even though teachers attested that they are trained in the use of computers. The findings are in the same view of Nnorom and 
African Journal of Educational Studies in Mathematics and Sciences Vol. 16, No. 2, 2020

Okoli (2014), who noted that most existing instructional resources are not used continuously for teaching.

Among the characteristics of a qualified teacher include not only having a welldeveloped knowledge of content but also a master of pedagogical content knowledge (Sabel et al., 2015). Those skills values may be earned when various instructional resources are regularly in the hands of instructors and used for teaching pre-service science teachers. Therefore, their absence implies that the production of poorly trained biology teachers may occur as a poor use of instructional resources can be linked to poor performance and skills acquisition.

\section{Conclusion and Recommendations}

The act of ascertaining the status of availability of biology instructional resources for teaching pre-service biology teachers is not only beneficial to private universities in Rwanda but also to all teacher-training universities and colleges over the world moreover especially to those that have participated in the study. The study revealed that some biology instructional resources are available while others are not, and the available instructional resources are not utilized positively. With this

\section{Acknowledgment}

We thank the African Centre of Excellence for Innovative Teaching and Learning Mathematics and Science (ACEITLMS) for financially supporting this study to be entirely conducted. We also thank the Private universities that participated in the study, and we appreciated the review comments from Kizito NDIHOKUBWAYO notification, it is an imperative need to train pre-service biology teachers with various categories of biology instructional resources. This need is essential because, with instructional resources, pre-service biology teachers earn excellent, transferable skills they need as the time ahead biology instructors in this dynamic world. Instructional resources must be available in various categories for the teaching and learning of biology as they enable instructors to explain the concepts concretely. Based on the findings of this study, researchers recommend that three selected Private Universities and other pre-service biology teacher-training colleges must hold with them required instructional resources. Their presence will help training competent preservice biology teachers with the necessary skills they need for their future careers. For ensuring quality education, University leaders in charge of academics should monitor the way available instructional resources are used in teaching and encourage lecturers to use instructional resources in every session of biology. Their use will provide relevant and constructive practical experience to pre-service biology teachers. Further research to check the adequacy of available biology instructional resources was recommended too. 
Biology Instructional Resources Availability and Extent of their Utilization in Teaching PreService Biology Teachers

\section{References}

Adebule, S. ., \& Ayoola, O. . (2016). Impact of Instructional Materials on Students , Academic Performance in Mathematics in Secondary Schools in Ekiti. Research Journal of Educational Studies and Review, 2(1), 1-4.

Akram, S., \& Malik, K. (2012). Use of audiovisual aids for effective teaching of biology at secondary school level. Elixir International Journal, 50, 10597-10605.

Akuma, F. V., \& Callaghan, R. (2016). Framework for reducing teaching challenges relating to improvisation of science education equipment and materials in schools. Eurasia Journal of Mathematics, Science and Technology Education, 12(10), 2697-2717. https://doi.org/10.12973/eurasia.2016.130 $5 \mathrm{a}$

Arokoyu, A. A., \& Chimuanya, J. C. (2017). Biology Teachers Methods of Teaching and Academic Performance of Secondary School Students in Abia State. Nigeria. Journal of Emerging Trends in Educational Research and Policy Studies (JETERAPS), 8(4), 228-231.

Arop, B. A., Umanah, F. I., \& Effiong, O. J. I. E. (2015). Effect of Instructional materials on the teaching and learning of Basic Science in Junior secondary schools in Cross River State, Nigeria. Global Journal of Educational Research, 14, 67-73.

Basheer, S., \& Ambreen Razzaq. (2012). Munich Personal RePEc Archive Impact of College Library on Student's Academic Achievements Impact of College Library on Student's Academic Achievement s. International Journal of Economics Business and Management Studies, 1(1), 1-8.

Belachew, W. (2020). Optimizing Pre-service Chemistry Teachers Understanding in Reaction Related Concepts of Aliphatic Hydrocarbons. Eurasia Journal of Mathematics, Science and Technology
J. Mukagihana, F. Nsanganwimana, C. M. Aurah

Education, $\quad$ 16(9), em1875. https://doi.org/10.29333/ejmste/8359

Bitok, Bekyibe, E. (2014). Availability of Information and Communication Technology Resources in Teaching and Learning of Biology by Secondary Schools in Uasin Gishu County, Kenya. International Journal of Science and Research (IJSR), 3(10), 1-7. https://www.ijsr.net/archive/v3i10/T0NU MTQ3NTE=.pdf

Bizimana Benjamin, \& Orodho, J. A. (2014). Teaching and learning resource availability and teachers' effective classroom management and content delivery in secondary schools in Huye District, Rwanda. Journal of Education and Practice, 5(9), 111-122.

Bosibori, O., Dr, G. N., K., R. N., Wesonga, \& Justus, N. (2015). Effect of Availability of Teaching and Learning Resources on the Implementation of Inclusive Education in Pre-School Centers. Journal of Education and Practice, 6(35), 10.

Byusa, E., Kampire, E., \& Mwesigye, A. R. (2020a). Analysis of Teaching Techniques and Scheme of Work in Teaching Chemistry in Rwandan Secondary Schools. EURASIA Journal of Mathematics, Science and Technology Education, 16(6), 9.

Byusa, E., Kampire, E., \& Mwesigye, A. R. (2020b). Ways School Leaders Support the Teaching of Chemistry. African Journal of Educational Studies in Mathematics and Sciences, 16(1), 63-72.

Cunningham, S. C., Mcnear, B., Pearlman, R. S., \& Kern, S. E. (2006). Beverage-Agarose Gel Electrophoresis: An Inquiry-based Laboratory Exercise with Virtual Adaptation 1. CBE-Life Sciences Education, 5, 281-286. https://doi.org/10.1187/cbe.06

Effiong, Ekpo, O., \& Igiri Charles. (2015). Impact of instructional materials in teaching and learning of biology in senior secondary schools in Yakurr LG A. 
African Journal of Educational Studies in Mathematics and Sciences Vol. 16, No. 2, 2020

International Letters of Social and Humanistic Sciences, $62,8$. https://doi.org/10.18052/www.scipress.co $\mathrm{m} / \mathrm{ILSHS} .62 .27$

Fraenkel, J. R., Wallen, N. E., \& Hyun, H. H. (2012). How to Design and Evaluate Research in Education (8th ed.). McGraw Hill.

Iji, C., Ogbole, P., \& Uka, N. (2014). Effect of Improvised Instructional Materials on Students' Achievement in Geometry at the Upper Basic Education Level in Makurdi Metropolis, Benue State, Nigeria. 2(7), 538-542.

https://doi.org/10.12691/education-2-7-17

Johnson, H. J., \& Cotterman, M. E. (2015). Developing preservice teachers' knowledge of science teaching through video clubs. Journal of Science Teacher Education, 26(4), 393-417. https://doi.org/10.1007/s10972-015-94290

Min, H., Noh, H. J., \& Paik, S.-H. (2017). Communities of Practice for Student Assessment in a South Korean Middle School. In Eurasia Journal of Mathematics, Science and Technology Education (Vol. 13, Issue 10).

Mukuka, A., Balimuttajjo, \& Sudi. (2020). Applying the SOLO Taxonomy in assessing and fostering Students Mathematical Problem-solving Abilities. Problems of Education in the 21st Century, 77(6), 13.

Musah, A., \& A., A, U. (2017). Effects of Availability and Utilization of Biology Laboratory Facilities and Students , Academic Achievements in Secondary Schools in Yobe State, Nigeria. International Journal of Innovative Social \& Science Education Research, 5(2), 1-8.

Naing, N. N. (2003). Determination of sample size. Malaysian Journal of Medical Sciences, 10(2), 84-86.

Ndihokubwayo, K., Uwamahoro, J., \& Ndayambaje, I. (2020). Implementation of the Competence-Based Learning in
Rwandan Physics Classrooms: First Assessment Based on the Reformed Teaching Observation Protocol. EURASIA Journal of Mathematics, Science and Technology Education, 16(9), 1-8.

Ndihokubwayo Kizito, Habiyaremye Hashituky Telesphore, R. J. C. (2019). Why Did Rwanda Shift from Knowledge to Competence Based Curriculum? Syllabuses and Textbooks Point of View. International Multi-Disciplinary Journal Bahir Dar, Ethiopia, 12(3), 12. https://doi.org/10.4314/afrrev.v12i3.4

Ngendahayo, E., \& Williams, H. A.-. (2016). Rwanda's new competence-based school curriculum.

Niyukuri, F., Nzotungicimpaye, J., \& Ntahomvukiye, C. (2020). Pre-service Teachers' Secondary School Experiences in Learning Geometry and their Confidence to Teach it. Eurasia Journal of Mathematics, Science and Technology Education, $\quad 16(8), \quad 1-12$. https://doi.org/10.29333/ejmste/8334

Nnorom, R. N., \& Okoli, G. A. (2014). The Status of Resources for Teaching Biology in Colleges of Education in Anambra State. Coo Interdisciplinary Research Journal, 1(1), 1-8.

Obomanu, B. J. (2011). Resources for Teaching Secondary School Biology In Bayelsa State of Nigeria. Information and Knowledge Management, 1(2).

Okpechi, P., \& Denwigwe, C. P. (2017). The Teacher and Teaching with Instructional Materials in the Teaching of Science subjects and the Contribution of Guidance and Counselors therein. British Journal of Education, 5(13), 1-9. https://doi.org/10.1017/CBO97811074153 24.004

Ong'amo, B. L., Ondigi, S. R., \& Omariba, A. (2017). Effect of Utilization of Biology Teaching and Learning Resources on Students Academic Performance in Secondary Schools in Siaya District Kenya. International Journal of Education 
Biology Instructional Resources Availability and Extent of their Utilization in Teaching PreService Biology Teachers

\section{J. Mukagihana, F. Nsanganwimana, C. M. Aurah}

and Research, 5(1), 2-20.

Oren, F. S. (2017). Which Technologies Do PreService Teachers Prefer to Use While Presenting Their Teaching Skills and for What Purposes Do They Use These Technologies? Higher Education Studies, $7(3)$, 103.

https://doi.org/10.5539/hes.v7n3p103

Pietzner, V. (2014). Computer-based learning in chemistry classes. Eurasia Journal of Mathematics, Science and Technology Education, 10(4), 297-311. https://doi.org/10.12973/eurasia.2014.108

$4 \mathrm{a}$

Romero-Tena, R., Lopez-Lozano, L., \& Gutierrez, M. P. (2020). Types of use of technologies by Spanish early childhood teachers. European Journal of Educational Research, 9(2), 511-522. https://doi.org/10.12973/eu-jer.9.2.511

Sabel, J. L., Forbes, C. T., \& Zangori, L. (2015). Promoting prospective elementary teachers' learning to use formative assessment for life science Instruction. Journal of Science Teacher Education, 26(4), 419-445. https://doi.org/10.1007/s10972-015-94316

Sasson, I., Kalir, D., \& Malkinson, N. (2020). The role of pedagogical practices in novice teachers' work. European Journal of Educational Research, 9(2), 457-469. https://doi.org/10.12973/eu-jer.9.2.457

Sonmez, D., \& Hakverdi-Can, M. (2012). Videos as an Instructional Tool in Preservice Suggested Citation: Eurasian Journal of Educational Research, 46, 141158.

Tan, T. T. M., Tan, Z. Y., \& Tan, W. L. (2007). Gel Electrophoresis. Biochemistry and Molecular Biology Education, 35(5), 342349. https://doi.org/10.1002/bambed.83

Tuimur, H. N., \& Chemwei, B. (2015). Availability and Use of Instructional Materials in the Teaching of Conflict and Conflict Resolution in Primary Schools in
Nandi North District, Kenya. International Journal of Education and Practice, 3(6), 224-234.

https://doi.org/10.18488/journal.61/2015.3 .6./61.6.224.234 